\title{
Editorial: Serotonin and Memory
}

\author{
Alfredo Meneses $^{1 *}$ and Antonella Gasbarri ${ }^{2}$ \\ ${ }^{1}$ Departamento de Farmacobiología, Centro de Investigación y de Estudios Avanzados del Instituto Politécnico Nacional, \\ Mexico City, Mexico, ${ }^{2}$ Department of Applied Clinical and Biotechnologic Sciences, University of L'Aquila, L'Aquila, Italy
}

Keywords: serotonin, neural markers, therapeutic targets, memory, short-term, memory, long-term, memory disorders

\section{The Editorial on the Research Topic}

\section{Serotonin and Memory}

Several neurotransmission systems have been involved in function and dysfunctional memory (e.g., Myhrer, 2003; Decker and McGaugh, 2004; Reis et al., 2009; Cassel, 2010; Rodríguez et al., 2012; Komal and Nashmi, 2015), including serotonin (5-hydroxytryptamine, 5-HT), which accounts with multiple neural markers (receptors, transporter; e.g., Hannon and Hoyer, 2008; Saulin et al., 2012; Seyedabadi et al., 2014; McCorvy and Roth, 2015). Indeed, the 5-HT system can be manipulated in multiple ways with pharmacological tools and possesses well characterized downstream signaling in mammals' species (e.g., Marin et al., 2012; McCorvy and Roth, 2015). Emergent evidence indicates that this monoamine system might be a therapeutic target and neural marker regarding function and dysfunctional memory. This issue presents recent advances including the role of 5- $\mathrm{HT}_{2 \mathrm{~A}}$ and $5-\mathrm{HT}_{1 \mathrm{~A}}$ receptors in the medial prefrontal cortex during recognition memory (Morici et al.). Hippocampal 5- $\mathrm{HT}_{1 \mathrm{~A}}$ receptors and spatial and memory is revised by Glikmann-Johnston et al. Ochoa et al. report that post-training serotonergic depletions of the basolateral amygdala did not disrupt discrimination, retention or reversal learning; suggesting that this serotonergic activity is not required for formation and flexible adjustment of new stimulus-reward associations when the strategy to efficiently solve the task has already been learned. Hernández-Pérez et al. report that serotonin reduction in the supramammillary nucleus alters place learning and concomitant hippocampal, septal, and supramammillar theta activity in spatial memory. Zhang and Stackman review progress in the $5-\mathrm{HT}_{2 \mathrm{~A}}$ receptor distribution, signaling, polymerization, and allosteric modulation; as well as functions in learning and memory, hallucination and spatial cognition, and mental disorders. Pereira et al. show us that $5-\mathrm{HT}_{6}$ receptor agonism facilitates emotional learning and involves prefrontal cortex and hippocampal signaling. Serotonergic transporter function is reported by Sivamaruthi et al. demonstrating that cronobacter sakazakii infection alters serotonin transporter and improved fear memory retention. Stiedl et al. discuss the role of the serotonin receptor subtypes $5-\mathrm{HT}_{1 \mathrm{~A}}$ and $5-\mathrm{HT}_{7}$ and their interaction in emotional learning and memory; including the role of these receptors and their interplay at the molecular, neurochemical, and behavioral level. The potential involvement of serotonergic neural markers with respect to memory is reviewed by Meneses.

Special mention and thanks to the expert work of the referees, who made professional and careful reviews that improved the papers in this topic.

\section{AUTHOR CONTRIBUTIONS}

BG support as referee in several papers. AM was editor. 


\section{REFERENCES}

Cassel, J. C. (2010). "Experimental studies on the role(s) of serotonin in learning and memory functions," in Handbook of the Behavioral Neurobiology of Serotonin, Vol. 21, eds C. P. Muller and B. L. Jacobs (Amsterdam: Academic Press), 429-448.

Decker, M. W., and McGaugh, J. L. (2004). The role of interactions between the cholinergic system and other neuromodulatory systems in learning and memory. Synapse 7, 151168. doi: 10.1002/syn.8900 70209

Hannon, J., and Hoyer, D. (2008). Molecular biology of 5-HT receptors. Behav. Brain Res. 195, 198-213. doi: 10.1016/j.bbr.2008.03.020

Komal, P., and Nashmi, R. (2015). T-cell receptors modify neuronal function in the central nervous system. Biochem. Pharmacol. 97, 512-517. doi: 10.1016/j.bcp.2015.07.023

Marin, P., Becamel, C., Dumuis, A., and Bockaert, J. (2012). 5-HT receptorassociated protein networks: new targets for drug discovery in psychiatric disorders? Curr. Drug Targets 13, 28-52. doi: 10.2174/1389450127988 68498

McCorvy, J. D., and Roth, B. L. (2015). Structure and function of serotonin G protein-coupled receptors. Pharmacol. Ther. 150, 129-142. doi: 10.1016/j.pharmthera.2015.01.009

Myhrer, T. (2003). Neurotransmitter systems involved in learning and memory in the rat: a meta-analysis based on studies of four behavioral tasks. Brain Res. Rev. 41, 268287. doi: 10.1016/S0165-0173(02)00268-0
Reis, H. J., Guatimosim, C., Paquet, M., Santos, M., Ribeiro, F. M., Kummer, A., et al. (2009). Neuro-transmitters in the central nervous system and their implication in learning and memory processes. Curr. Med. Chem. 16, 796840. doi: 10.2174/092986709787549271

Rodríguez, J. J., Noristani, H. N., and Verkhratsky, A. (2012). The serotonergic system in ageing and Alzheimer's disease. Prog. Neurobiol. 99, 1541. doi: 10.1016/j.pneurobio.2012.06.010

Saulin, A., Savli, M., and Lanzenberger, R. (2012). Serotonin and molecular neuroimaging in humans using PET. Amino Acids. 42, 2039-2057. doi: 10.1007/s00726-011-1078-9

Seyedabadi, M., Fakhfouri, G., Ramezani, V., Mehr, S. E., and Rahimian, R. (2014). The role of serotonin in memory: interactions with neurotransmitters and downstream signaling. Exp. Brain Res. 232, 723-738. doi: 10.1007/s00221-0133818-4

Conflict of Interest Statement: The authors declare that the research was conducted in the absence of any commercial or financial relationships that could be construed as a potential conflict of interest.

Copyright (C) 2016 Meneses and Gasbarri. This is an open-access article distributed under the terms of the Creative Commons Attribution License (CC BY). The use, distribution or reproduction in other forums is permitted, provided the original author(s) or licensor are credited and that the original publication in this journal is cited, in accordance with accepted academic practice. No use, distribution or reproduction is permitted which does not comply with these terms. 